\title{
MODELAGEM NUMÉRICA DE ESCOAMENTO TRANSIENTE EM MEIOS POROSOS ALEATÓRIOS SATURADOS USANDO A EXPANSÃO DE KARHUNEN-LOÈVE
}

\author{
Juarez dos Santos Azevedo \\ Orientador: Dr. Saulo Pomponet Oliveira (UFPR) \\ 111 p. - Tese (Doutorado) - Defesa 13.03.2009
}

\begin{abstract}
RESUMO. Um requisito importante de um modelo geofísico é a capacidade de quantificar a incerteza associada à imprecisão e/ou a escassez de dados de campo. Uma maneira de realizar esta quantificação é descrever o modelo por meio de equações diferenciais cujos parâmetros associados a propriedades materiais são processos estocásticos. Os métodos de elementos finitos estocásticos são apresentados como um procedimento eficiente na caracterização da solução de equações de evolução com coeficientes estocásticos. Os conceitos de projeção, ortogonalidade e convergência fraca são utilizados para gerar problemas determinísticos auxiliares que são resolvidos por métodos de elementos finitos tradicionais. Em particular, a expansão de Karhunen-Loève é usada para discretizar os parâmetros estocásticos dentro de um conjunto enumerável de variáveis aleatórias. Os modelos estudados neste trabalho são baseados na Lei de Darcy para fluxo saturado nos regimes permanente e transiente em que a condutividade hidráulica segue uma distribuição lognormal. A solução numérica no regime permanente foi realizada pelos métodos de Monte Carlo, Galerkin espectral, das equações de Momentos baseado na expansão de Karhunen-Loève e da Colocação, visando identificar os benefícios e deficiências de cada método. 0 método da Colocação mostrou-se mais atrativo que os métodos de Galerkin espectral e de Momentos. No regime transiente mantevese o foco nos métodos de Monte Carlo e da Colocação. Estes métodos fornecem uma previsão da média e da variância do potencial hidráulico nos poços de produção a partir das propriedades estatísticas da condutividade hidráulica. Critérios de otimização são aplicados nestes métodos a fim de se estudar a hidráulica de poços em aqǘferos livres e extensos fixando distâncias mínimas entre poços de produção.
\end{abstract}

ABSTRACT. An important requirement of a geophysical model is the ability to quantify the uncertainty associated with inaccurate and/or limited field data. One way to accomplish this quantification is to describe the model with differential equations whose parameters associated with material properties are stochastic processes. Stochastic finite element methods are presented as an efficient procedure for the characterization of the solution of dynamic problems with stochastic coefficients. The concepts of projection, orthogonality, and weak convergence are employed to generate auxiliary, deterministic problems that are solved by standard finite element methods. In particular, the Karhunen-Loève expansion is used to discretize the stochastic parameters within a set of countable random variables. The models studied in this work are based on Darcy's Law for steady and transient saturated flow in which the hydraulic conductivity follows a lognormal distribution. Numerical solutions in the steady case are computed by the following methods: Monte Carlo, spectral Galerkin, the Moment-equation approach based on KL decomposition, and Collocation, in order to identify the advantages and difficulties of each method. The Collocation method outperformed the spectral Galerkin and the Moment-equation methods. The Monte Carlo and Collocation methods are focused in the study of the transient regime. These methods provide an estimate of the mean and the covariance of the hydraulic potential of production wells from the statistical properties of the hydraulic conductivity. Optimization criteria are applied in order to study the hydraulics of wells in free, unbounded aquifers by setting minimum distances between production wells. 